\title{
Original paper \\ Vandermeerscheite, a new uranyl vanadate related to carnotite, from Eifel, Germany
}

\author{
Jakub PLÁŠIL 1*, Anthony R. KAMPF², Radek ŠKODA³, Jiří ČEJKA ${ }^{4}$ \\ ${ }^{1}$ Institute of Physics, Academy of Sciences of the Czech Republic v.v.i, Na Slovance 1999/2, 18221 Prague 8, Czech Republic; plasil@fzu.cz \\ ${ }^{2}$ Mineral Sciences Department, Natural History Museum of Los Angeles County, 900 Exposition Boulevard, Los Angeles, CA 90007, USA \\ ${ }^{3}$ Department of Geological Sciences, Faculty of Science, Masaryk University, Kotlárská 2, 611 37, Brno, Czech Republic \\ ${ }^{4}$ Department of Mineralogy and Petrology, National Museum, Cirkusová 1740, 19300 Prague 9, Czech Republic \\ * Corresponding author
}

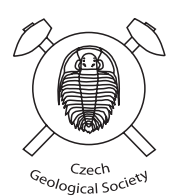

Vandermeerscheite (IMA2017-104), $\mathrm{K}_{2}\left[\left(\mathrm{UO}_{2}\right)_{2} \mathrm{~V}_{2} \mathrm{O}_{8}\right] \cdot 2 \mathrm{H}_{2} \mathrm{O}$, is a new uranyl-vanadate mineral from the Schellkopf quarry, Eifel, Germany. The new mineral occurs in cavities of volcanic rocks, mostly growing on phillipsite-K. It forms rosettelike aggregates of thin blades up to $50 \mu \mathrm{m}$ long. Crystals are flattened on $\{10 \overline{1}\}$, and elongated on [101], with crystal forms $\{010\},\{10 \overline{1}\}$ and $\{111\}$; crystals are transparent with a vitreous luster. Vandermeerscheite is non-fluorescent under both long- and short-wavelength ultraviolet radiation. The Mohs hardness is $\sim 2$. The calculated density is 4.502 $\mathrm{g} \cdot \mathrm{cm}^{-3}$ based on the empirical formula; $4.507 \mathrm{~g} \cdot \mathrm{cm}^{-3}$ for the ideal formula. Vandermeerscheite dissolves easily in dilute $\mathrm{HCl}$ at room temperature. The new mineral is biaxial (-), with $\alpha=1.83$ (calc.), $\beta=1.90(1), \gamma=1.91(1)$ (measured in white light at $22^{\circ} \mathrm{C}$ ). The measured $2 \mathrm{~V}$ is $40(10)^{\circ}$ estimated from conoscopic observation of interference figure; dispersion is moderate $r<v$. No pleochroism was observed. Optical orientation is $X \approx \perp\{10 \overline{1}\}, Y \approx[101], Z=\mathbf{b}$. The empirical formula of vandermeerscheite (on the basis of $14 \mathrm{O}$ apfu) is $\left(\mathrm{K}_{1.87} \mathrm{Ca}_{0.05} \mathrm{Na}_{0.04}\right)_{\Sigma 1.96}\left[\left(\mathrm{U}_{1.005} \mathrm{O}_{2}\right)_{2} \mathrm{~V}_{1.99} \mathrm{O}_{8}\right] \cdot 2 \mathrm{H}_{2} \mathrm{O}$. Raman spectrum is dominated by the vibrations of $\mathrm{UO}_{2}{ }^{2+}$ and $\mathrm{V}_{2} \mathrm{O}_{8}$ units. Vandermeerscheite is monoclinic, $P 2, l n, a=8.292$ (2), $b=8.251(3), c=10.188(3) \AA, \beta=110.84(3)^{\circ}, V=651.4(4) \AA^{3}$, and $Z=2$. The seven strongest powder X-ray diffraction

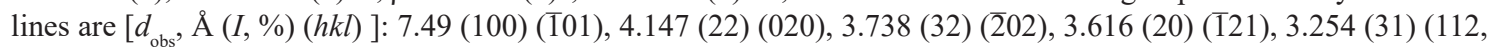
$121), 3.132$ (21) (122, 022), $2.989(41)(211,013)$. The crystal structure of vandermeerscheite was refined from the single-crystal X-ray data to $R=0.0801$ for 644 independent observed reflections, with $I_{\text {obs }}>3 \sigma(I)$. The structure, which differs from carnotite in symmetry, is based upon uranyl vanadate sheets of francevillite topology; in the interlayer, there are $\mathrm{K}^{+}$cations and $\mathrm{H}_{2} \mathrm{O}$ groups that provide inter-sheet linkage. The new mineral honors Belgian amateur mineralogist and famous mineral photographer Eddy Van Der Meersche, who discovered the new mineral.

Keywords: vandermeerscheite, uranyl vanadate, new mineral, carnotite group, crystal structure

Received: 16 May 2019; accepted: 26 September 2019; handling editor: J. Sejkora

The online version of this article (doi: 10.3190/jgeosci.288) contains supplementary electronic material.

\section{Introduction}

Uranyl-vanadate minerals are relatively insoluble over a range of $\mathrm{pH}$ conditions (circumneutral and alkaline) and they are quite abundant in Colorado Plateau-type U-V deposits, as well as in the mine and mill tailings (Evans and Garrels 1958; Dahlkamp 1993; Spano et al. 2017; Kampf et al. 2019). The most well-known and abundant of these is carnotite, $\mathrm{K}_{2}\left(\mathrm{UO}_{2}\right)_{2}\left(\mathrm{~V}_{2} \mathrm{O}_{8}\right) \cdot n \mathrm{H}_{2} \mathrm{O}$ (where $n$ is usually given in the range 1-3). Here we describe a new mineral from Schellkopf, Eifel (Germany), vandermeerscheite, $\mathrm{K}_{2}\left[\left(\mathrm{UO}_{2}\right)_{2} \mathrm{~V}_{2} \mathrm{O}_{8}\right] \cdot 2 \mathrm{H}_{2} \mathrm{O}$, which is chemically closely related to carnotite.

Vandermeerscheite is named in honor of prominent Belgian amateur mineralogist, mineral collector and distinguished mineral photographer Eddy Van Der Meersche (born 1945) living in Ghent, Belgium. He has long been convinced that this rarely found carnotiterelated mineral from Schellkopf - first noted in 1983 by Hentschel and investigated in 1993 by Piret and co-workers - is a new species and provided us with specimens for a new, detailed study. This new mineral description is based on three cotype specimens deposited in the collections of the Natural History Museum of Los Angeles County, 900 Exposition Boulevard, Los Angeles, CA 90007, USA, catalogue numbers 67260, 67261 and 67262 . The new mineral and the name have been approved by the International Mineralogical Association (IMA2017-104).

\section{Occurrence}

The new mineral was found in the quarry at Schellkopf near Brenk, Eifel, Rhineland-Palatinate, Germany. The quarry is located in a c. 380,000 year-old phonolitic dome, composed of dense porphyric selbergite that deforms strata of Devonian shales (Cruse 1986; Meyer 
1988). In the massive and fine-grained rock, rich in potassium, phenocrysts of nosean are abundant. Sanidine, leucite and titanite are less common. The supergene mineralization is partly pneumatolytic, but mostly hydrothermal, and is located in small vugs. The vug walls are mostly covered with zeolites (most commonly "phillipsite", frequently gonnardite intergrown with paranatrolite and occasionally analcime, gismondine- $\mathrm{Ca}$, chabazite- $\mathrm{Ca}$ and thomsonite-Ca). Calcite occurs in various habits. White spheres composed of curved zeophyllite crystals also occur frequently. Ettringite, sometimes partially transformed into thaumasite, can be found. The quarry is the type locality for brenkite (Hentschel et al. 1978). Fluorite occurs as greyish worm-like aggregates. Vandermeerscheite was found in the cavities growing on

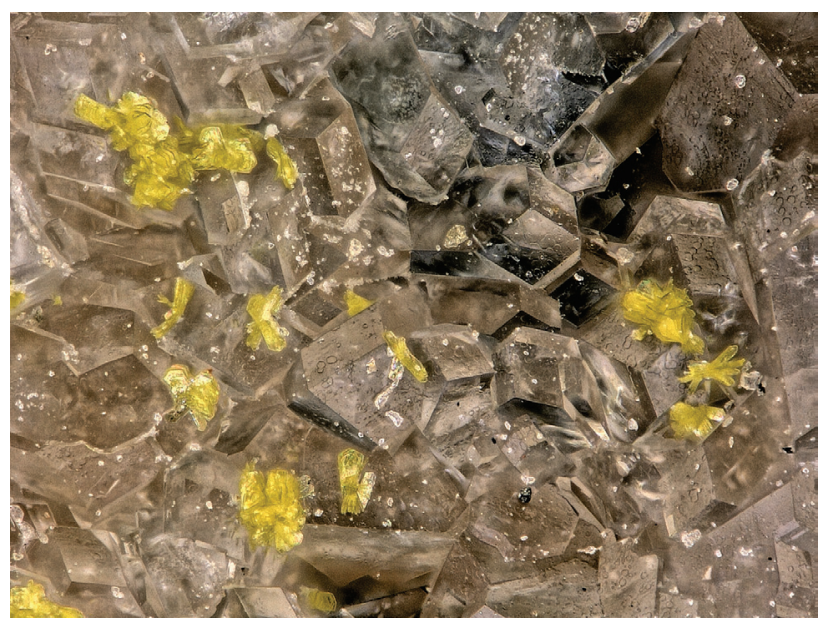

Fig. 1 Vandermeerscheite crystals on "phillipsite-K". Cotype specimen. Width of the photograph is $0.8 \mathrm{~mm}$.

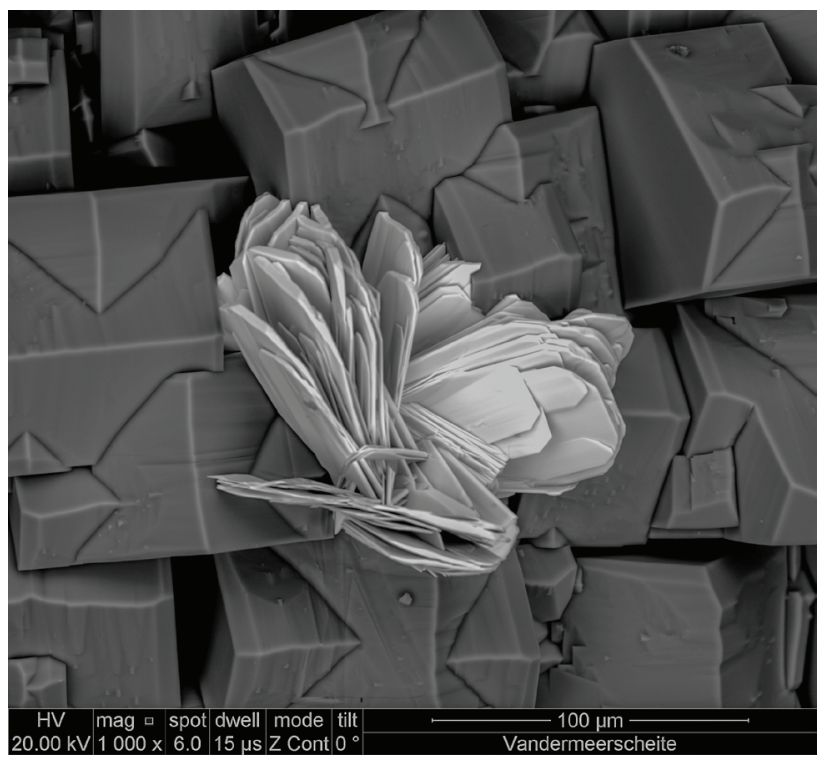

Fig. 2 Typical rosette-like aggregate of vandermeerscheite crystals on "phillipsite-K" crystals. Back-scattered electron image (photo by E. Van Der Meersche and Herman Goethals).
phillipsite-K (Fig. 1) and, rarely, on fluorite. Sometimes it forms also as inclusions in calcite.

\section{Physical and optical properties}

Vandermeerscheite occurs in crystals, which are thin blades up to $50 \mu \mathrm{m}$ long, forming sub-parallel and divergent aggregates (Fig. 2). Crystals are flattened on $\{10 \overline{1}\}$, and elongated on [101], with the crystal forms: $\{010\},\{10 \overline{1}\}$ and $\{111\}$ (Fig. 3). Crystals are transparent with a vitreous luster. The mineral has a yellow streak. Vandermeerscheite is non-fluorescent under both long- and short-wavelength ultraviolet radiation. The Mohs hardness is about 2. Crystals are brittle with perfect cleavage on $\{10 \overline{1}\}$ and have curved fracture. The calculated density is $4.502 \mathrm{~g} \cdot \mathrm{cm}^{-3}$ based on the empirical formula; $4.507 \mathrm{~g} \cdot \mathrm{cm}^{-3}$ for the ideal formula. Vandermeerscheite dissolves easily in dilute $\mathrm{HCl}$ at room temperature.

Optically, vandermeerscheite is biaxial (-), with $\alpha=$ 1.83 (calc.), $\beta=1.90(1), \gamma=1.91$ (1) (measured in white light at $\left.22^{\circ} \mathrm{C}\right)$. The measured $2 \mathrm{~V}$ is $40(10)^{\circ}$ estimated from conoscopic observations of the interference figure; dispersion is moderate $r<v$. No pleochroism was observed. Optical orientation is $X \approx \perp\{10 \overline{1}\}, Y \approx[101]$, $Z=\mathbf{b}$. Note that $X$ is perpendicular to the thin direction of the tiny blades, making $\alpha$ impossible to measure; consequently, it was calculated from $\beta, \gamma$ and $2 V$.

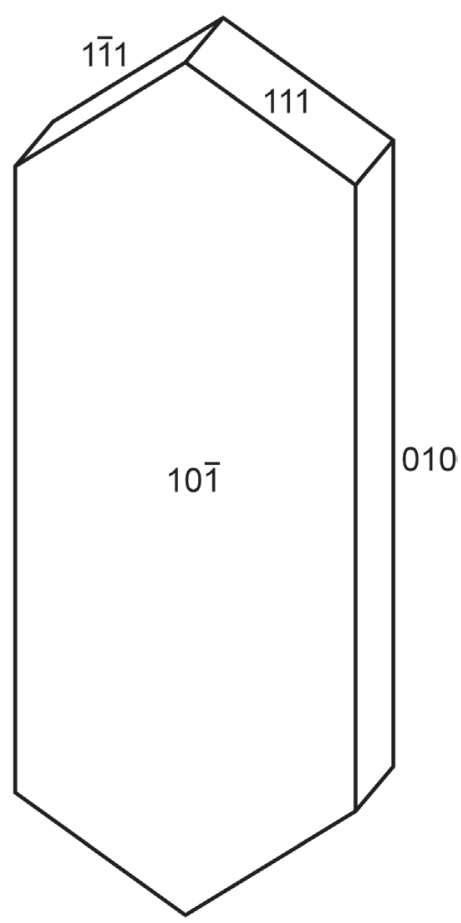

Fig. 3 Crystal drawing of vandermeerscheite; clinographic projection in nonstandard orientation, [101] vertical. 
Tab. 1 Chemical composition (in wt. \%) for vandermeerscheite

\begin{tabular}{lrccl}
\hline Constituent & Mean & Range & Stand. Dev. & Probe Standard \\
\hline $\mathrm{Na}_{2} \mathrm{O}$ & 0.13 & $0.01-0.26$ & 0.08 & albite \\
$\mathrm{K}_{2} \mathrm{O}$ & 9.85 & $8.99-10.26$ & 0.40 & sanidine \\
$\mathrm{CaO}$ & 0.30 & $0.21-0.43$ & 0.06 & fluorapatite \\
$\mathrm{V}_{2} \mathrm{O}_{5}$ & 20.30 & $19.40-20.30$ & 0.61 & $\mathrm{ScVO}_{4}$ \\
$\mathrm{UO}_{3}$ & 64.41 & $61.79-66.41$ & 1.49 & parsonsite \\
$\mathrm{H}_{2} \mathrm{O}^{*}$ & 4.04 & & & \\
Total & 99.03 & & & \\
\hline
\end{tabular}

$*$ as determined from crystal structure

\section{Chemical composition}

A crystal aggregate of vandermeerscheite crystals was analyzed (Tab. 1) using a Cameca SX100 electron microprobe (Masaryk University, Brno), operating in WDS mode with an accelerating voltage of $15 \mathrm{kV}$, beam current of $2 \mathrm{nA}$, and a $5 \mu \mathrm{m}$ beam diameter. The following $\mathrm{X}$-ray lines and standards were used: $K_{\alpha}$ lines: $\mathrm{Na}$ (albite), $\mathrm{K}$ (sanidine), $\mathrm{Ca}$ (fluorapatite), $\mathrm{V}$ (synth. $\mathrm{ScVO}_{4}$ ); $M_{\alpha}$ line: $\mathrm{U}$ (parsonsite). Other likely elements, such as $\mathrm{Si}$, $\mathrm{Al}, \mathrm{S}, \mathrm{P}, \mathrm{K}, \mathrm{V}$ and $\mathrm{F}$ were also sought, but their contents were below the detection limits $(\sim 0.05-0.15$ wt. $\%$ with the analytical conditions used). The peak counting times (CT) were 10 or $20 \mathrm{~s}$ and the counting time for each background was $50 \%$ of the peak CT. The raw data were reduced using the $X-\varphi$ matrix correction routine (Merlet 1994). As insufficient material is available for the direct determination of $\mathrm{H}_{2} \mathrm{O}$, it has been calculated based on the results of the structure refinement (based on: $\mathrm{U}+\mathrm{V}=4$ apfu and $\mathrm{O}=14 \mathrm{apfu}$ ).

The empirical formula on the basis of $14 \mathrm{O}$ apfu is $\left(\mathrm{K}_{1.87} \mathrm{Ca}_{0.05} \mathrm{Na}_{0.04}\right)_{\Sigma 1.96}\left[\left(\mathrm{U}_{1.005} \mathrm{O}_{2}\right)_{2} \mathrm{~V}_{1.99} \mathrm{O}_{8}\right] \cdot 2 \mathrm{H}_{2} \mathrm{O}$. The ideal structural formula is $\mathrm{K}_{2}\left[\left(\mathrm{UO}_{2}\right)_{2} \mathrm{~V}_{2} \mathrm{O}_{8}\right] \cdot 2 \mathrm{H}_{2} \mathrm{O}$, which requires $\mathrm{K}_{2} \mathrm{O} 10.65, \mathrm{UO}_{3} 64.70, \mathrm{~V}_{2} \mathrm{O}_{5} 20.57, \mathrm{H}_{2} \mathrm{O} 4.08$, total 100 wt. \%. The Gladstone-Dale compatibility, $1-\left(\mathrm{K}_{\mathrm{p}} / \mathrm{K}_{\mathrm{c}}\right.$ ), for vandermeerscheite is -0.020 (excellent), using the ideal formula, and -0.023 (excellent) using the empirical formula, where $k\left(\mathrm{UO}_{3}\right)=0.134$, as provided by Larsen (1921).

\section{Raman spectroscopy}

The Raman spectrum of vandermeerscheite (Fig. 4) was collected on Jobin-Yvon Labram HR, using a grid of 600 lines/ $\mathrm{mm}, 100 \times$ objective lens and

Fig. 4 Raman spectrum of vandermeerscheite. utilizing a $633 \mathrm{~nm}$ laser. Spectral calibration was done on Ne-emission lines using a low-pressure Ne-discharge lamp.

There were no bands of significant intensities observed in the region of $\mathrm{O}-\mathrm{H}$ stretching vibrations. A very weak band at $1605 \mathrm{~cm}^{-1}$ may be assignable to the $v_{2}(\delta) \mathrm{H}-\mathrm{O}-\mathrm{H}$ bending vibration of $\mathrm{H}_{2} \mathrm{O}$ and those at 1463 and $1072 \mathrm{~cm}^{-1}$ are most probably overtones or combination bands. A medium strong band at $970 \mathrm{~cm}^{-1}$ is attributed to the $v_{1} \mathrm{VO}_{3}$ symmetric stretching vibration of $\mathrm{V}_{2} \mathrm{O}_{8}$ dimers. Similar bands were observed in the spectra of carnotite $\left(975 \mathrm{~cm}^{-1}\right)$ and francevillite $(976$ $\mathrm{cm}^{-1}$ ) (Frost et al. 2005). A medium strong band at 820 $\mathrm{cm}^{-1}$ is attributed to the $v_{1} \mathrm{UO}_{2}{ }^{2+}$ symmetric stretching vibration. Some bands in the Raman spectrum of carnotite and francevillite (Frost et al. 2005) observed in the range from 950 to $850 \mathrm{~cm}^{-1}$ were assigned to the $v_{3}$ $\mathrm{UO}_{2}{ }^{2+}$ antisymmetric stretching vibrations; however, this IR-active vibration remains Raman inactive in the case of vandermeerscheite. The $\mathrm{U}-\mathrm{O}$ bond length in uranyl inferred from the $v_{1} \mathrm{UO}_{2}{ }^{2+}$ is approximately $1.79 \AA$ (Bartlett and Cooney 1989). This value is in line with that obtained from the structure (1.77 $\AA$ ) and the most frequent value for the uranyl in $\mathrm{UO}_{7}$ polyhedra given by Lussier et al. (2016). The band of highest intensity at $745 \mathrm{~cm}^{-1}$ is related to the $v_{2}$ or $v_{7}$ $\mathrm{VO}_{5}$ stretching vibrations (Frost et al. 2005). A weak band at $645 \mathrm{~cm}^{-1}$ may be attributed to libration modes of $\mathrm{H}_{2} \mathrm{O}$ or to the $v \mathrm{~V}_{2} \mathrm{O}_{2}$ stretching modes. Bands at 570 $\mathrm{cm}$ (medium strong), 533 (weak) and $475 \mathrm{~cm}^{-1}$ (weak) are assigned to the $v \mathrm{U}-\mathrm{O}_{\text {ligand }}$ vibrations. Bands at 409 (very weak), 375 (medium strong), 344 (medium strong) and $306 \mathrm{~cm}^{-1}$ (medium strong) are connected with the $\delta \mathrm{V}_{2} \mathrm{O}_{2}$ bending modes. A weak band at $231 \mathrm{~cm}^{-1}$ is connected with the doubly degenerate $v_{2}(\delta) \mathrm{UO}_{2}{ }^{2+}$ bending vibrations. Bands of low intensity at 198, 181, 166 and $118 \mathrm{~cm}^{-1}$ are assignable to phonons.

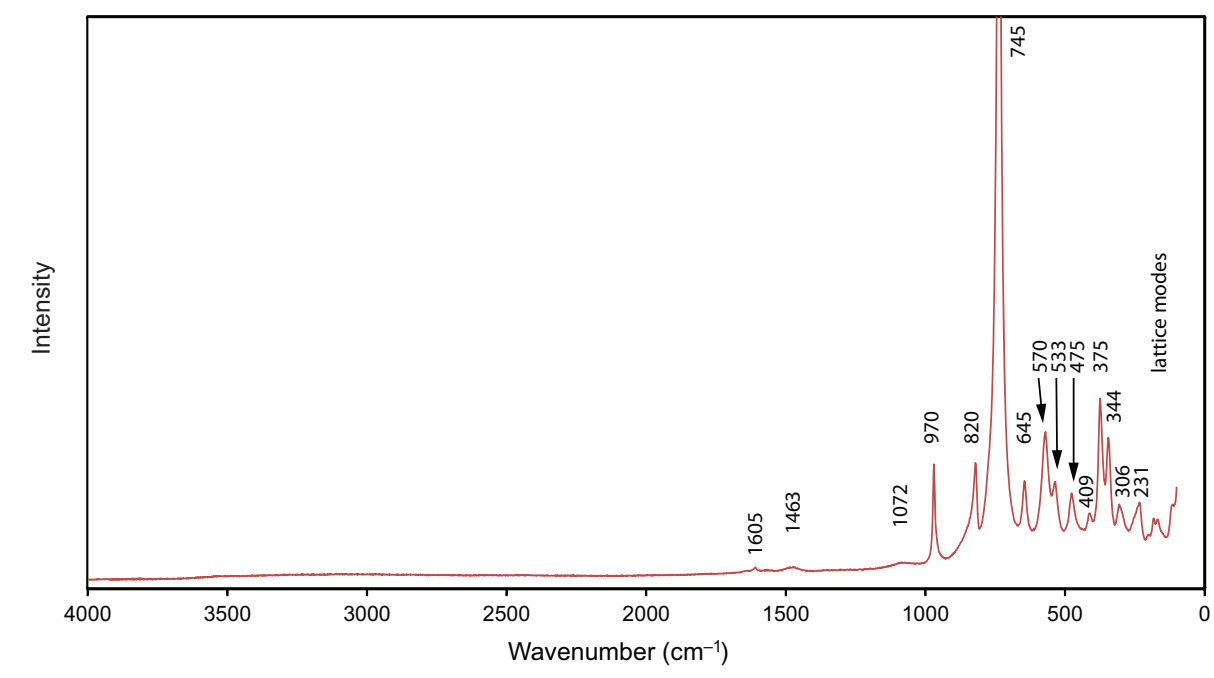


Tab. 2 Powder X-ray data ( $d$ in $\AA$ ) for vandermeerscheite

\begin{tabular}{|c|c|c|c|c|c|c|c|c|c|}
\hline$I_{\text {obs }}$ & $d_{\mathrm{obs}}$ & $d_{\text {calc }}$ & $I_{\text {calc }}$ & $h k l$ & $I_{\mathrm{obs}}$ & $d_{\mathrm{obs}}$ & $d_{\text {calc }}$ & $I_{\text {calc }}$ & $h k l$ \\
\hline 100 & 7.49 & 7.4455 & 100 & $\overline{1} 01$ & \multirow{3}{*}{12} & \multirow{3}{*}{2.0532} & 2.0699 & 2 & $\overline{4} 02$ \\
\hline 5 & 6.27 & 6.2355 & 9 & 011 & & & 2.0628 & 2 & 040 \\
\hline \multirow[t]{3}{*}{5} & 5.64 & 5.6487 & 5 & 110 & & & 2.0480 & 8 & 213 \\
\hline & & 5.5277 & 3 & $\overline{1} 11$ & \multirow{4}{*}{13} & & 2.0146 & 4 & 114 \\
\hline & & 5.1761 & 5 & 101 & & \multirow{3}{*}{2.0068} & 1.9933 & 3 & 140 \\
\hline 5 & 4.78 & 4.7607 & 7 & 002 & & & 1.9879 & 3 & $\overline{1} 41$ \\
\hline 5 & 4.41 & 4.3847 & 4 & 111 & & & 1.9859 & 5 & $\overline{4} 11$ \\
\hline 22 & 4.147 & 4.1255 & 22 & 020 & 12 & 1.9672 & 1.9588 & 6 & $\overline{2} 15$ \\
\hline 8 & 3.895 & 3.8748 & 9 & 200 & \multirow{3}{*}{11} & \multirow{3}{*}{1.9351} & 1.9438 & 3 & $\overline{4} 13$ \\
\hline \multirow[t]{2}{*}{32} & 3.738 & 3.7228 & 27 & $\overline{2} 02$ & & & 1.9370 & 4 & 312 \\
\hline & & 3.7002 & 7 & $\overline{2} 11$ & & & 1.9162 & 5 & 141 \\
\hline \multirow[t]{4}{*}{20} & 3.616 & 3.6086 & 21 & $\overline{1} 21$ & \multirow[t]{3}{*}{12} & \multirow[t]{3}{*}{1.9026} & 1.9017 & 2 & $\overline{1} 42$ \\
\hline & & 3.5073 & 3 & 210 & & & 1.8927 & 4 & 042 \\
\hline & & 3.3904 & 2 & $\overline{1} 03$ & & & 1.8829 & 4 & 330 \\
\hline & & 3.2487 & 22 & 112 & \multirow[t]{2}{*}{11} & \multirow[t]{3}{*}{1.8714} & 1.8674 & 2 & 134 \\
\hline \multirow{2}{*}{31} & 3.254 & 3.2261 & 8 & 121 & & & 1.8614 & 3 & $\overline{4} 04$ \\
\hline & & 3.1585 & 7 & $\overline{1} 22$ & \multirow[b]{2}{*}{4} & & 1.8555 & 4 & 015 \\
\hline \multirow[t]{2}{*}{21} & 3.132 & 3.1177 & 15 & 022 & & 1.8461 & 1.8501 & 2 & $\overline{4} 22$ \\
\hline & & 2.9933 & 20 & 211 & \multirow{2}{*}{5} & \multirow[b]{2}{*}{1.8107} & 1.8208 & 2 & 240 \\
\hline 41 & 2.989 & 2.9622 & 26 & 013 & & & 1.8043 & 3 & $\overline{2} 42$ \\
\hline 8 & 2.848 & 2.8244 & 7 & 220 & \multirow{2}{*}{6} & \multirow{2}{*}{1.7714} & 1.7671 & 3 & 204 \\
\hline \multirow[t]{2}{*}{10} & 2.776 & 2.7638 & 12 & $\overline{2} 22$ & & & 1.7622 & 3 & 143 \\
\hline & & 2.7528 & 2 & $\overline{3} 01$ & 5 & 1.7409 & 1.7389 & 4 & 411 \\
\hline \multirow[t]{2}{*}{7} & 2.649 & 2.6423 & 6 & 031 & \multirow{2}{*}{6} & 17113 & 1.7157 & 2 & $\overline{3} 25$ \\
\hline & 2607 & 2.6193 & 4 & 123 & & & 1.7134 & 2 & 105 \\
\hline 4 & 2.007 & 2.5919 & 2 & 130 & 5 & 16852 & 1.6967 & 5 & $\overline{4} 24$ \\
\hline & & 2.5750 & 3 & $\overline{3} 12$ & 3 & 1.0052 & 1.6762 & 3 & 233 \\
\hline & & 2.4818 & 3 & $\overline{3} 03$ & 8 & 1.6579 & 1.6577 & 4 & 134 \\
\hline 6 & 2.488 & 2.4652 & 3 & 310 & 9 & 1.6366 & 1.6427 & 2 & 116 \\
\hline & & 2.4307 & 4 & $\overline{1} 14$ & & & 1.6416 & 6 & $\overline{4} 31$ \\
\hline 7 & 2.436 & 2.4288 & 3 & 131 & & & 1.6262 & 2 & $\overline{2} 35$ \\
\hline & & 2.3995 & 2 & 132 & 5 & 1.6200 & 1.6251 & 2 & $\overline{5} 12$ \\
\hline & & 2.2898 & 2 & $\overline{3} 21$ & & & 1.6244 & 3 & 224 \\
\hline 5 & 2.179 & 2.1705 & 4 & 132 & & & 1.6137 & 2 & 332 \\
\hline 8 & 2.129 & 2.1267 & 6 & $\overline{3} 23$ & 5 & 15936 & 1.6053 & 2 & $\overline{3} 16$ \\
\hline 13 & 2091 & 2.1096 & 4 & $\overline{2} 24$ & J & & 1.5864 & 3 & $\overline{3} 43$ \\
\hline & & 2.0891 & 7 & 231 & 4 & 1.5700 & 1.5656 & 3 & 035 \\
\hline & & 2.0785 & 5 & 033 & & & & & \\
\hline
\end{tabular}

Only calculated lines with $I>1$ are shown

\section{Powder X-ray diffraction}

X-ray powder diffraction data were recorded using a Rigaku R-Axis Rapid II curved imaging plate microdiffractometer with monochromatized $\mathrm{Mo} K_{\alpha}$ radiation. A Gandolfi-like motion on the $\phi$ and $\omega$ axes was used to randomize the sample. Observed $d$ values and intensities were derived by profile fitting using JADE 2010 software. Data are given in Tab. 2. Unit-cell parameters refined from the powder data using JADE 2010 with whole pattern fitting are as follows: $a=8.336(4) \AA$, $b=8.282(4) \AA, c=10.214(4) \AA$, $\beta=110.78(2)^{\circ}, V=659.3(5)$ $\AA^{3}, Z=2$.

\section{Single-crystal X-ray diffraction}

The single-crystal X-ray study was done on a Rigaku SuperNova diffractometer with mirror-monochromatized $\mathrm{MoK}_{\alpha}$ radiation $(\lambda=0.71073 \AA)$ from a microfocus X-ray source detected by an Atlas S2 CCD detector. Integration of the data, including corrections for background, polarization and Lorentz effects, was carried out with the CrysAlis RED program. The absorption correction was finalized in the Jana2006 program (Petříček et al. 2014). The structure of vandermeerscheite was solved by the charge-flipping algorithm using the SHELXT program (Sheldrick 2015) and subsequently refined by the least-squares algorithm of the Jana2006 software based on $F^{2}$. Diffraction frames indicated the presence of a split crystal component; it had to be taken into account during the refinement process in Jana2006. The structure was refined in the centrosymmetric monoclinic space group $P 2_{1} / n$. The structure solution located all non-hydrogen atoms, except of those of the $\mathrm{H}_{2} \mathrm{O}$ sites in the interlayer that were later located from the differenceFourier maps. All sites were assigned full occupancies. The $\mathrm{H}$ atoms locations could not be found in the difference Fourier maps. Data collection and refinement details are given in Tab. 3, atom coordinates, displacement parameters and bond-valence sums in Tabs 4 and 5, and selected bond distances in Tab. 6. The bond-valence analysis was done using the DIST option in Jana2006 utilizing bond-valence parameters given in Burns et al. (1997) and Gagné and Hawthorne (2015). The crys- 
tallographic information file (cif) for vandermeerscheite is provided as Supplementary material and can be downloaded from http://dx.doi.org/10.3190/ jgeosci. 288 .

\subsection{Description of the crystal structure}

The structure of vandermeerscheite contains one $U$, one $\mathrm{V}$, one $\mathrm{K}$ and seven $\mathrm{O}$ sites in the asymmetric unit (Fig. 5a). The U1 site is linked to seven ligands, two $\mathrm{O}$ atoms with short $\mathrm{U} \equiv \mathrm{O}$ bonds (forming the uranyl ion, $\mathrm{UO}_{2}{ }^{2+}$ ) and five $\mathrm{O}$ atoms that are positioned in the equatorial plane of a squat pentagonal $\mathrm{UO}_{7}$ bipyramid. The V1 site is linked to five $\mathrm{O}$ atoms forming quite regular $\mathrm{VO}_{5}$ tetragonal pyramid; two $\mathrm{VO}_{5}$ pyramids, related by symmetry, share an edge, resulting in $\mathrm{V}_{2} \mathrm{O}_{8}$ dimers. The sheet (Fig. 5b), comprised of a mosaic of pairs of edgesharing $\mathrm{UO}_{7}$ bipyramids and edge-sharing $\mathrm{VO}_{4}$ pyramids, is of the well-known francevillite topology (Burns 2005; Lussier et al. 2016; Spano et al. 2017). Sheets are stacked parallel to $\{10 \overline{1}\}$. In the interlayer, are located the $\mathrm{K}^{+}$cations and a single $\mathrm{O}$ site corresponding to a $\mathrm{H}_{2} \mathrm{O}$ molecule, based on the bond-valence calculations (Tab. 4). Adjacent sheets, with interplanar distance of $7.45 \AA$, are linked by $\mathrm{K}-\mathrm{O}$ bonds and hydrogen bonds. The structural formula of vandermeerscheite obtained from the refinement is $\mathrm{K}_{2}\left[\left(\mathrm{UO}_{2}\right)_{2} \mathrm{~V}_{2} \mathrm{O}_{8}\right]$ $\left(\mathrm{H}_{2} \mathrm{O}\right)_{2}, \mathrm{Z}=2$.

\section{Discussion}

\subsection{Status of carnotite}

Vandermeerscheite resembles chemically carnotite, ideally $\mathrm{K}_{2}\left(\mathrm{UO}_{2}\right)_{2}\left(\mathrm{~V}_{2} \mathrm{O}_{8}\right) \cdot 3 \mathrm{H}_{2} \mathrm{O}$, the crystal structure of which remains vandermeerscheite
Tab. 3 Data collection and structure refinement details for vandermeerscheite

\begin{tabular}{|c|c|}
\hline Formula & $\mathrm{K}_{2}\left[\left(\mathrm{UO}_{2}\right)_{2} \mathrm{~V}_{2} \mathrm{O}_{8}\right]\left(\mathrm{H}_{2} \mathrm{O}\right)_{2}$ \\
\hline Crystal system & monoclinic \\
\hline Space group & $P 2_{1} / n$ \\
\hline Unit-cell parameters: $a, b, c[\AA]$ & $8.292(2), 8.251(3), 10.188(3)$ \\
\hline$\beta\left[^{\circ}\right]$ & $110.84(3)$ \\
\hline Unit-cell volume $\left[\AA^{3}\right]$ & $651.4(4)$ \\
\hline Z & 2 \\
\hline Calculated density $\left[\mathrm{g} / \mathrm{cm}^{3}\right]$ & 4.508 (for the abovementioned formula) \\
\hline Crystal size $[\mathrm{mm}]$ & $0.053 \times 0.022 \times 0.005$ \\
\hline Diffractometer & Rigaku SuperNova with Atlas S2 CCD \\
\hline Temperature $[\mathrm{K}]$ & 297 \\
\hline Radiation, wavelength $[\AA]$ & $\mathrm{Mo}_{a}, 0.71073(50 \mathrm{kV}, 40 \mathrm{~mA})$ \\
\hline$\theta$ range for data collection $\left[^{\circ}\right]$ & $3.61-22.67$ \\
\hline Limiting Miller indices & $h=-10 \rightarrow 10, k=-7 \rightarrow 10, l=-12 \rightarrow 10$ \\
\hline Axis, frame width $\left({ }^{\circ}\right)$, time per frame $(\min )$ & $\omega, 1.0,400$ \\
\hline Total reflections collected & 4090 \\
\hline Unique reflections & 1474 \\
\hline Unique observed reflections, criterion & $644,[I>3 \sigma(I)]$ \\
\hline Absorption coefficient $\left[\mathrm{mm}^{-1}\right]$, type & 26.88; spherical + empirical scaling \\
\hline$T_{\min } / T_{\max }$ & $0.035 / 0.063$ \\
\hline Data completeness from $\theta_{\max }(\%), R_{\text {int }}$ & $82 \%, 0.129$ \\
\hline Structure refinement & Jana2006; Full-matrix least-squares on $F^{2}$ \\
\hline No. of param., restraints, constraints & $52,0,0$ \\
\hline$R, w R$ (obs) & $0.0801,0.1723$ \\
\hline$R, w R$ (all) & $0.1864,0.2339$ \\
\hline GOF obs/all & $1.31,1.19$ \\
\hline Weighting scheme, weights & $\sigma, w=1 /\left(\sigma^{2}(I)+0.0 .0035999999 I^{2}\right)$ \\
\hline Largest diffraction peak and hole $\left(\mathrm{e}^{-} / \AA^{3}\right)$ & $10.40(0.06 \AA$ to $\mathrm{U} 1),-11.72$ \\
\hline \multirow{3}{*}{ Twin matrix; twin fractions } & $\left(\begin{array}{lll}-1 & -0.0243 & 0.0083\end{array}\right)$ \\
\hline & $0.0329 ; 0.77(7), 0.23(7)$ \\
\hline & $-0.0088 \quad 0.0143$ \\
\hline
\end{tabular}

unknown. Only the structure of synthetic anhydrous carnotite has been published (Sundberg and Sillen 1949; Appleman and Evans 1965). Although the structural re-

Tab. 4 Atom coordinates, displacement parameters $\left(\AA^{2}\right)$ and bond-valence sums (in valence units) for

\begin{tabular}{|c|c|c|c|c|c|}
\hline Atom & $x / a$ & $y / b$ & $z / c$ & $U_{\mathrm{eq}} / U_{\text {iso }}{ }^{*}$ & $\sum \mathrm{BV}$ \\
\hline U1 & $0.82153(16)$ & $0.52122(13)$ & $0.81490(15)$ & $0.0250(5)$ & $6.3(2)$ \\
\hline V1 & $0.6079(8)$ & $0.3542(7)$ & $0.5000(7)$ & $0.029(2)$ & $5.12(19)$ \\
\hline K1 & $0.6875(12)$ & $0.5650(10)$ & $0.1709(11)$ & $0.047(4)$ & $0.93(3)$ \\
\hline O1 & $0.616(3)$ & $0.558(2)$ & $0.600(3)$ & $0.023(5)^{*}$ & $2.04(6)$ \\
\hline $\mathrm{O} 2$ & $0.660(3)$ & $0.468(3)$ & $0.885(3)$ & $0.036(6)^{*}$ & $2.03(12)$ \\
\hline $\mathrm{O} 3$ & $0.527(3)$ & $0.154(2)$ & $0.473(3)$ & $0.020(5)^{*}$ & $2.11(11)$ \\
\hline O4 & $0.979(4)$ & $0.578(3)$ & $0.745(4)$ & $0.046(7)^{*}$ & $1.98(14)$ \\
\hline O5 & $0.764(3)$ & $0.292(2)$ & $0.674(3)$ & $0.031(6)^{*}$ & $1.93(7)$ \\
\hline O6 & $0.723(3)$ & $0.377(3)$ & $0.407(3)$ & $0.036(6)^{*}$ & $2.05(17)$ \\
\hline $\mathrm{O} 7$ & $0.908(4)$ & $0.733(3)$ & $0.417(4)$ & $0.055(8)^{*}$ & $0.24(1)$ \\
\hline
\end{tabular}

Tab. 5 Anisotropic atomic displacement parameters for vandermeerscheite

\begin{tabular}{lllllll}
\hline Atom & \multicolumn{1}{c}{$U^{11}$} & \multicolumn{1}{c}{$U^{22}$} & \multicolumn{1}{c}{$U^{33}$} & $U^{12}$ & \multicolumn{1}{c}{$U^{13}$} & $U^{23}$ \\
\hline U1 & $0.0209(7)$ & $0.0296(7)$ & $0.0104(7)$ & $-0.0005(5)$ & $-0.0118(5)$ & $-0.0018(6)$ \\
V1 & $0.030(4)$ & $0.031(3)$ & $0.010(3)$ & $0.001(2)$ & $-0.012(3)$ & $0.000(2)$ \\
K1 & $0.037(5)$ & $0.061(5)$ & $0.026(6)$ & $-0.006(4)$ & $-0.008(5)$ & $0.005(4)$ \\
\hline
\end{tabular}


Tab. 6 Selected interatomic distances $(\AA)$ for vandermeerscheite

\begin{tabular}{|c|c|c|c|c|c|}
\hline $\mathrm{U} 1-\mathrm{O} 1$ & $2.27(2)$ & $\mathrm{V} 1-\mathrm{O} 1$ & $1.95(2)$ & $\mathrm{K} 1-\mathrm{O} 2^{\mathrm{iv}}$ & $2.95(3)$ \\
\hline $\mathrm{U} 1-\mathrm{O} 2$ & $1.78(3)$ & $\mathrm{V} 1-\mathrm{O} 1^{\mathrm{iii}}$ & $1.91(2)$ & $\mathrm{K} 1-\mathrm{O} 2^{\mathrm{iii}}$ & $2.75(3)$ \\
\hline $\mathrm{U} 1-\mathrm{O}^{\mathrm{i}}$ & $2.35(2)$ & $\mathrm{V} 1-\mathrm{O} 3$ & $1.77(2)$ & $\mathrm{K} 1-\mathrm{O} 4^{\mathrm{v}}$ & $2.84(3)$ \\
\hline $\mathrm{U} 1-\mathrm{O} 3^{\mathrm{ii}}$ & $2.37(2)$ & $\mathrm{V} 1-\mathrm{O} 5$ & $1.86(3)$ & K1-O6 & $2.79(3)$ \\
\hline $\mathrm{U} 1-\mathrm{O} 4$ & $1.76(4)$ & V1-O6 & $1.58(4)$ & $\mathrm{K} 1-\mathrm{O}^{\mathrm{vi}}$ & $2.86(3)$ \\
\hline $\mathrm{U} 1-\mathrm{O} 5$ & $2.32(2)$ & $<V 1-\Phi_{e q}>$ & 1.87 & $\mathrm{~K} 1-\mathrm{O} 7$ & $2.88(3)$ \\
\hline $\mathrm{U} 1-\mathrm{O} 5^{\mathrm{i}}$ & $2.36(2)$ & & & $\mathrm{K} 1-\mathrm{O} 7^{\mathrm{vii}}$ & $2.90(3)$ \\
\hline$<U 1-O_{U r}>$ & 1.77 & & & $<K 1-\Phi_{e q}>$ & 2.82 \\
\hline$<U 1-\Phi_{e q}>$ & 2.33 & & & & \\
\hline$\overline{\mathrm{O} 1-\mathrm{O} 1^{\mathrm{iii}}}$ & $2.44(3)$ & $\mathrm{O} 2-\mathrm{O} 5$ & $2.97(5)$ & O5-O6 & $2.71(5)$ \\
\hline $\mathrm{O} 1-\mathrm{O} 2$ & $2.89(4)$ & $\mathrm{O} 2-\mathrm{O} 5^{\mathrm{i}}$ & $2.85(3)$ & & \\
\hline $\mathrm{O} 1-\mathrm{O} 3^{\mathrm{iii}}$ & $2.64(3)$ & $\mathrm{O} 2-\mathrm{O} 7^{\text {viii }}$ & $3.00(5)$ & & \\
\hline $\mathrm{O} 1-\mathrm{O} 4$ & $2.85(3)$ & $\mathrm{O} 3-\mathrm{O} 3^{\mathrm{ix}}$ & $2.67(3)$ & & \\
\hline $\mathrm{O} 1-\mathrm{O} 5$ & $2.50(3)$ & $\mathrm{O} 3-\mathrm{O} 4^{\mathrm{viii}}$ & $2.95(5)$ & & \\
\hline $\mathrm{O} 1-\mathrm{O} 5^{\mathrm{i}}$ & $2.89(3)$ & $\mathrm{O} 3-\mathrm{O} 4^{\mathrm{x}}$ & $2.92(4)$ & & \\
\hline O1-O6 & $2.85(4)$ & $\mathrm{O} 3-\mathrm{O} 5$ & $2.55(3)$ & & \\
\hline $\mathrm{O} 1-\mathrm{O} 6^{\mathrm{iii}}$ & $2.84(4)$ & O3-O6 & $2.69(4)$ & & \\
\hline $\mathrm{O} 2-\mathrm{O}^{\mathrm{i}}$ & $2.92(3)$ & $\mathrm{O} 4-\mathrm{O} 5$ & $2.89(3)$ & & \\
\hline
\end{tabular}

Symmetry codes: (i) $-x+3 / 2, y+1 / 2,-z+3 / 2$; (ii) $x+1 / 2,-y+1 / 2, z+1 / 2$; (iii) $-x+1,-y+1,-z+1$; (iv) $x, y$, $z-1$; (v) $-x+2,-y+1,-z+1$; (vi) $-x+3 / 2, y+1 / 2,-z+1 / 2$; (vii) $-x+3 / 2, y-1 / 2,-z+1 / 2$; (viii) $-x+3 / 2, y-1 / 2$, $-z+3 / 2$; (ix) $-x+1,-y,-z+1 ;$ (x) $x-1 / 2,-y+1 / 2, z-1 / 2$.

lationship between vandermeerscheite and fully hydrated carnotite is not known, the comparison of the available powder diffraction patterns of natural carnotite samples (for instance RRUFF file R070345; Lafuente et al. 2015) and the vandermeerscheite pattern shows apparent differences (Tab. 7).

a)

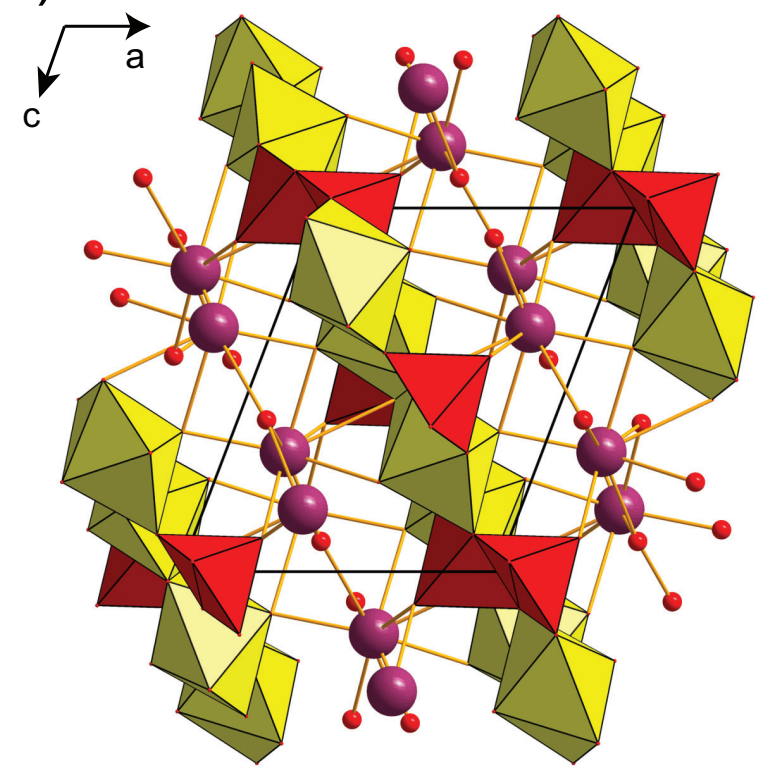

\subsection{Relations to other uranyl vanadates}

The powder pattern of vandermeerscheite is very similar to that of synthetic $\mathrm{Ni}\left[\left(\mathrm{UO}_{2}\right)_{2} \mathrm{~V}_{2} \mathrm{O}_{8}\right] \cdot 4 \mathrm{H}_{2} \mathrm{O}$ (Borène and Cesbron 1970) (Tab. 7); however, the structures are clearly distinct. The regular octahedral coordination of $\mathrm{Ni}$ is quite different from the large irregular coordination polyhedron of the $\mathrm{K}^{+}$cation, resulting in a higher $\mathrm{H}_{2} \mathrm{O}$ content in $\mathrm{Ni}\left[\left(\mathrm{UO}_{2}\right)_{2} \mathrm{~V}_{2} \mathrm{O}_{8}\right] \cdot 4 \mathrm{H}_{2} \mathrm{O}$ than in vandermeerscheite (Fig. 6a-b).

Vandermeerscheite is yet another mineral containing the uranyl-vanadate sheet of the francevillite uranyl-anion topology. There are fourteen mineral species (see the overview in Krivovichev and Plášil 2013 or Spano et al. 2017) possessing structures based upon this type of sheet; however, some of these remain poorly defined structurally. Interestingly, there is a common mistake in the older literature: the composition of the sheets is expressed as $\left[\left(\mathrm{UO}_{2}\right)_{2}\left(\mathrm{VO}_{4}\right)_{2}\right]$. While this is formally correct, keeping the

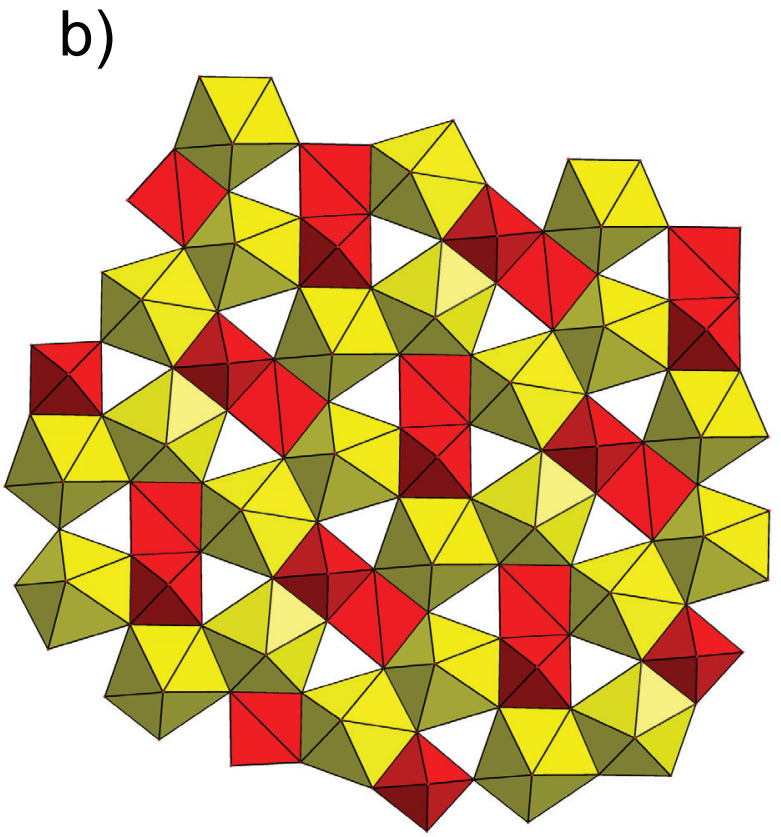

Fig. 5 Crystal structure of vandermeerscheite: $\mathbf{a}-$ Viewed down [010]. Uranyl-vanadate sheets $\left(\mathrm{UO}_{7}=\mathrm{yellow}\right.$, VO $=$ red) alternate interlayer with $\mathrm{K}^{+}$cations (violet) and $\mathrm{H}_{2} \mathrm{O}$ molecules (red spheres representing $\mathrm{O}$ atoms). Unit-cell edges are displayed in black solid line; b - Uranyl-vanadate sheet of the francevillite topology in vandermeerscheite $\left(\mathrm{UO}_{7}=\right.$ yellow, $\mathrm{VO}_{5}=$ red). 
overall stoichiometry, it implies the presence of $\mathrm{VO}_{4}$ tetrahedra, which is incorrect. All structures with francevillite-type sheets contain dimers of $\mathrm{VO}_{5}$ square pyramids, thus $\mathrm{V}_{2} \mathrm{O}_{8}$ groups.

\subsection{Environmental implications}

Uranyl vanadates are environmentally important products of supergene weathering of primary $U$ ores, such as uraninite. They occur abundantly in Colorado Plateau-type U-V deposits (Evans and Garrels 1958; Dahlkamp 1993). Probably the most abundant uranyl vanadate is carnotite, $\mathrm{K}_{2}\left[\left(\mathrm{UO}_{2}\right)_{2} \mathrm{~V}_{2} \mathrm{O}_{8}\right] \cdot 3 \mathrm{H}_{2} \mathrm{O}$. Over a range of conditions, it is among the most insoluble U(VI) minerals. Due to their insolubility, uranyl vanadates effectively retain uranium in natural systems, where vanadium is present. Carnotite is stable in the $\mathrm{pH}$ range of 4.5-8, and the Eh range of 1.0-0.0 V (Langmuir 1978; Schindler et al. 2000). For example, the solubility of carnotite in groundwater is very low, having been noted as being approximately $1 \mathrm{ppb} U$ in the $\mathrm{pH}$ range of 5.5-7.5 (Barton 1958). Car-
Tab. 7 Selected data for vandermeerscheite and related minerals and synthetic compounds

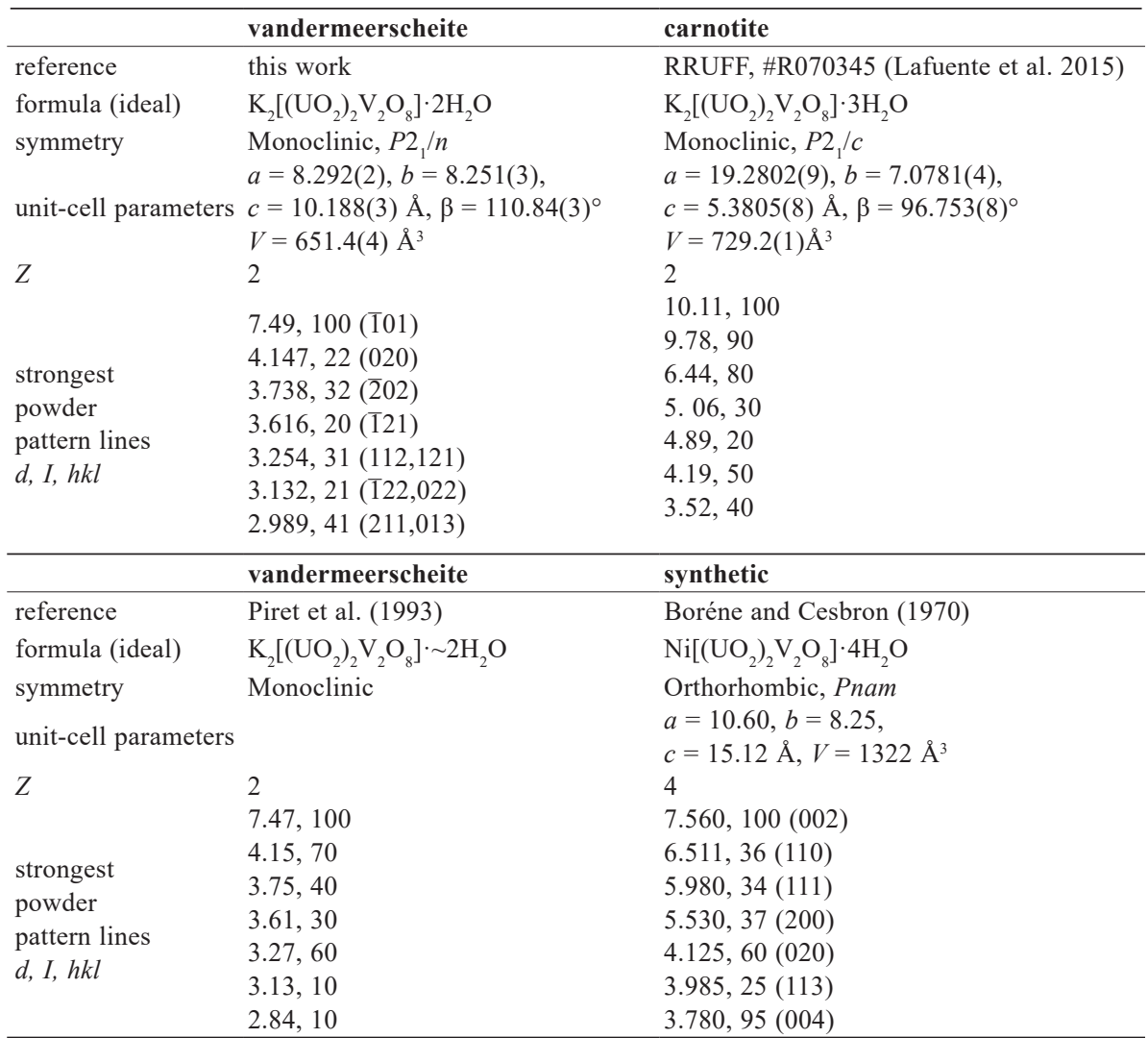

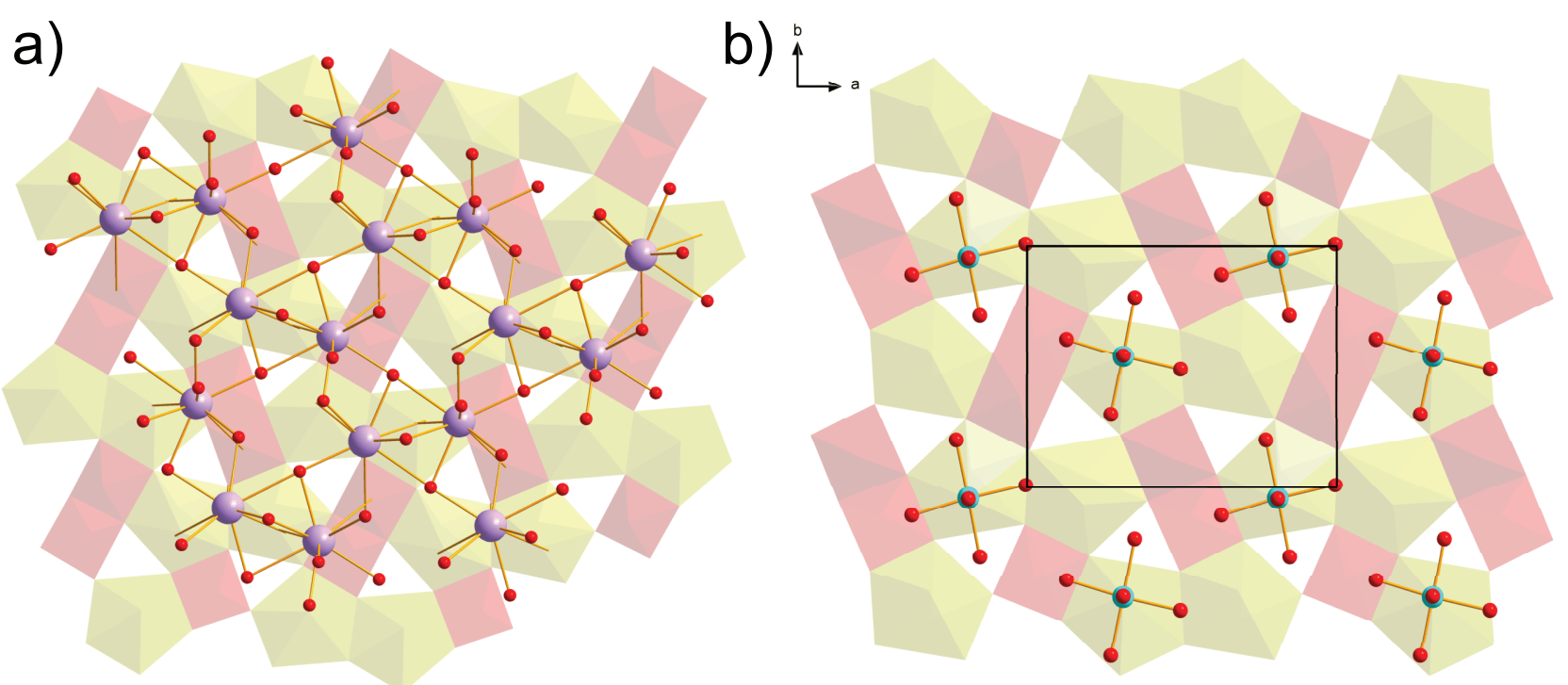

Fig. 6 Configurations of interlayer constituents in the crystal structure of vandermeerscheite $(\mathbf{a})$ and synthetic $\mathrm{Ni}\left[\left(\mathrm{UO}_{2}\right)_{2} \mathrm{~V}_{2} \mathrm{O}_{8}\right] \cdot 4 \mathrm{H}_{2} \mathrm{O}(\mathbf{b})$. $\mathrm{UO}_{7}=$ yellow, $\mathrm{VO}_{5}=$ red, $\mathrm{K}$ (violet), $\mathrm{O}=$ red, $\mathrm{Ni}=$ azure. Unit-cell edges are displayed in black solid line. 
Vandermeerscheite is another uranyl vanadate that should be considered environmentally important. Its close chemical similarity to carnotite suggests that some of the earlier reported occurrences for carnotite, based on EDX analysis, may, in fact, correspond to vandermeerscheite.

Acknowledgements. We thank Herman Goethals (Royal Belgian Institute of Natural Sciences, Brussels, Belgium) for his cooperation with SEM photography. This paper benefited from constructive reviews of Travis Olds and an anonymous referee. This work was financially supported by the Czech Science Foundation (project GACR 17-09161S) to JP and by the by the Ministry of Culture of the Czech Republic (long-term project DKRVO 20192023/1II.a; National Museum 00023272) to JČ.

Electronic supplementary material. Supplementary crystallographic data are available online at the Journal web site (http://dx.doi.org/10.3190/jgeosci.288).

\section{References}

Appleman DE, Evans HT (1965) The crystal structures of synthetic anhydrous carnotite, $\mathrm{K}_{2}\left(\mathrm{UO}_{2}\right)_{2} \mathrm{~V}_{2} \mathrm{O}_{8}$, and its cesium analogue, $\mathrm{Cs}_{2}\left(\mathrm{UO}_{2}\right)_{2} \mathrm{~V}_{2} \mathrm{O}_{8}$. Amer Miner 50: 825-842

BARTLETT JR, COONEY RP (1989) On the determination of uranium-oxygen bond lengths in dioxouranium(VI) compounds by Raman spectroscopy. J Mol Struct 193: 295-300

BARTON PB (1958) Synthesis and properties of carnotite and its alkali analogues. Amer Miner 43: 799-817

BorÈne J, CESBRon F (1970) Structure cristalline de l'uranylvanadate de nickel tetrahydraté $\mathrm{Ni}\left(\mathrm{UO}_{2}\right)_{2}\left(\mathrm{VO}_{4}\right)_{2} \cdot 4 \mathrm{H}_{2} \mathrm{O}$. Bull Soc franç Minéral Cristallogr 93: 426-432

BuRns PC (2005) $\mathrm{U}^{6+}$ minerals and inorganic compounds: insights into an expanded structural hierarchy of crystal structures. Canad Mineral 43: 1839-1894

Burns PC, Ewing R, Hawthorne, FC (1997) The crystal chemistry of hexavalent uranium: polyhedron geometries, bond-valence parameters, and polymerization of polyhedra. Canad Mineral 35: 1551-1570

Cruse B (1986) Der Schellkopf bei Brenk, Eifel. Geologische, petrografische und mineralogische Beobachtungen. Aufschluss 36: 149-161

DahlKamp FJ (1993) Uranium Ore Deposits. SpringerVerlag, Berlin, pp 1-135

EVANS HT, GARRELS RM (1958) Thermodynamic equilibria of vanadium in aqueous systems as applied to the interpretation of the Colorado Plateau ore deposits. Geochim Cosmochim Acta 15: 131-149

Frost RL, Čejka J, Weier ML, Martens W, Henry DA (2005) Vibrational spectroscopy of selected natural uranyl vanadates. Vib Spec 39: 131-138
GaGné OC, Hawthorne FC (2015) Comprehensive derivation of bond-valence parameters for ion pairs involving oxygen. Acta Crystallogr B71: 562-578

Hentschel G (1983) Der Schellkopf bei Brenk. Lapis 8(9): 18-25

Hentschel G, Leufer U, Tillmanns E (1978) Brenkit, ein neues Kalzium-Fluor-Carbonat von Schellkopf/Eifel. Neu Jb Mineral, Mh 1978: 325-329

Kampf AR, PlášIl J, Nash BP, Marty J (2019) Ammoniomathesiusite, a new uranyl sulfate-vanadate mineral from the Burro mine, San Miguel County, Colorado, USA. Mineral Mag 83: 115-121

KrivovicheV SV, PláŠIL J (2013) Mineralogy and crystallography of uranium. In: Burns PC, SigMON GE (eds) Uranium: From Cradle to Grave. Mineralogical Association of Canada Short Courses 43: pp 15-119

Lafuente B, Downs RT, Yang H, Stone N (2015) The power of databases: the RRUFF project. In: ARMBRUSTER T, DANISI RM (eds) Highlights in Mineralogical Crystallography. W. De Gruyter, Berlin, pp 1-30

LANGMUIR D (1978) Uranium solution-mineral equilibria at low temperatures with applications to sedimentary ore deposits. Geochim Cosmochim Acta 42: 547-569

LARSEN ES (1921) The microscopic determination of the nonopaque minerals. US Geol Surv Bull 679: pp 1-294

Lussier AJ, Lopez AK, Burns PC (2016) A revised and expanded structure hierarchy of natural and synthetic hexavalent uranium compounds. Canad Mineral 54: 177-283

Meyer W (1988) Geologie der Eifel, 2 ${ }^{\text {nd }}$ Ed. E.Schweizerbart'sche Verlagsbuchhandlung, Stuttgart, pp 1-615

MerLet C (1994) An accurate computer correction program for quantitative electron probe microanalysis. Microchim Acta: 114/115: 363-376

Petř́́čEK V, DuŠEK M, PALATINus L (2014) Crystallographic computing system Jana2006: general features. Z Kristallogr 229: 345-352

Piret P, Hentschel G, Deliens M, Van Der Meersche E (1993) Ein mit Carnotit verwandtes Kalium-Uranylvanadat vom Schellkopf bei Brenk, Eifel. Aufschluss 44: 291-294

Rigaku (2017) CrysAlis CCD and CrysAlis RED. RigakuOxford Diffraction Ltd, Yarnton, Oxfordshire, UK

Schindler M, Hawthorne FC, Baur WH (2000) Crystal chemical aspects of vanadium: polyhedral geometries, characteristic bond valences, and polymerization of $\left(\mathrm{VO}_{n}\right)$ polyhedra. Chem Mater 12: 1248-1259

SHELDRICK GM (2015) SHELXT - integrated space-group and crystal-structure determination. Acta Crystallogr A71: 3-8

Spano TL, Dzik EA, Sharifironizi M, Dustin MK, TurnER M, BURNS PC (2017) Thermodynamic investigation of uranyl vanadate minerals: implications for structural stability. Amer Miner 102: 1149-1153 
Sundberg I, Sillen L G (1949) On the crystal structure of $\mathrm{KUO}_{2} \mathrm{VO}_{4}$ (synthetic anhydrous carnotite). Ark Kemi Mineral Geol 1: 337-351
Tokunaga TK, Kim Y, Wan J (2009) Potential remediation approach for uranium-contaminated groundwaters through potassium uranyl vanadate precipitation. Environ Sci Technol 43: 5467-5471 